\title{
Conceptual Framework of Low Carbon Strategy for Nepal
}

\author{
Sunil Prasad Lohani, Bivek Baral \\ Department of Mechanical Engineering, Kathmandu University, Kathmandu, Nepal. \\ Email: splohani@ku.edu.np
}

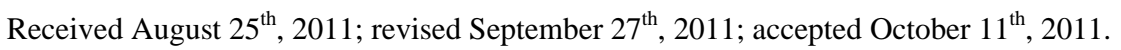

\begin{abstract}
This paper presents proposed methodologies for carbon mitigation strategy and expected frame for low carbon strategy for Nepal. It deals with the national scenario of energy consumption in different sectors and the share of fuel types in each sector. Based on national energy situation green house gas (GHG) emissions in each area are evaluated. With the use of both fuel types in energy mix, end use energy conversion technology and current GHG trend; potential energy related green house gas mitigation areas are identified. Moreover, non energy related probable GHG reduction areas are also identified. The outcome of this work will facilitate to realize the vision of low carbon society through sustainable development pathway as it helps in formulating a comprehensive strategy and action plan for low carbon strategy for Nepal.
\end{abstract}

Keywords: Green House Gas, Mitigation, Energy Mix

\section{Introduction}

The concept of low carbon society has originated as a response to mitigate greenhouse (GHG) gases, which are considered to be responsible for global warming and climate change. The basic activities of a modern society, including production of goods and service, and transportation should have near zero carbon emissions or have minimum value to cease or at least hold back the global warming phenomenon, which has come up as one of the biggest challenges to modern human civilization.

Since the industrial revolution, humans have extensively exploited the resources of the nature which resulted in upsetting of the delicate balance of the global environment. It has been predicted by several studies that if the global warming phenomenon is not confined within a limit, the results would be catastrophic.

The gases including carbon dioxide $\left(\mathrm{CO}_{2}\right)$, methane $\left(\mathrm{CH}_{4}\right)$, nitrous oxide $\left(\mathrm{N}_{2} \mathrm{O}\right)$, hydrofluorocarbons (HFCs), perfluorocarbons (PFCs) and sulphur hexafluoride $\left(\mathrm{SF}_{6}\right)$ are considered to be direct greenhouse gases which are the direct results of fossil fuel combustion $\left(\mathrm{CO}_{2}\right)$, land use and agricultural activities $\left(\mathrm{CO}_{2}, \mathrm{CH}_{4}\right.$ and $\left.\mathrm{N}_{2} \mathrm{O}\right)$ and industrial activities (HFCs, PFCs and $\mathrm{SF}_{6}$ ). Apart from those gases, the gases including carbon monoxide (CO), sulphur dioxide $\left(\mathrm{SO}_{2}\right)$, oxides of nitrogen $\left(\mathrm{NO}_{\mathrm{X}}\right)$ and non-methane volatile organic compounds (NMVOCs) are considered to be the indirect greenhouse gases. However, the most significant gases in terms of their potential harmfulness and amount of production are $\mathrm{CO}_{2}, \mathrm{CH}_{4}$, $\mathrm{N}_{2} \mathrm{O}$, HFCs, PFCs and $\mathrm{SF}_{6}$. Kyoto Protocol also requires the removals of the direct greenhouse gases. However, GHGs are critical in maintaining the average earth temperature at around $15^{\circ} \mathrm{C}$; without them, the earth temperature would dip down to $-18^{\circ} \mathrm{C}$ and life on earth would cease to exist. If the greenhouse gases are emitted within a certain limit they are recycled back to nature and held in the form of organic compounds in the vegetations and do not cause any harm to the global environment. When the balance of this cycle is not maintained due to excessive GHG emissions, the temperature of the earth will increase. During the period between industrial revolution and recent years (1850 to 1998), approximately $270( \pm 30)$ Gt of carbon was released into the atmosphere as carbon dioxide $\left(\mathrm{CO}_{2}\right)$ as a result of fossil fuel combustion and cement production (67\% of the total), and land use and land use change (remaining 33\%) [1]. About $40 \%$ of these emissions remain in the atmosphere while the other $60 \%$ was assumed to be absorbed by the ocean and terrestrial ecosystems. Thus, during the period 1850 to 1998, the atmospheric $\mathrm{CO}_{2}$ concentration increased by about $28 \%$, i.e. from $285 \mathrm{ppmv}$ at the end of 19th century to $366 \mathrm{ppmv}$ at the end of 20th Century [1]. This increased 
$\mathrm{CO}_{2}$ concentration is believed to be causing an increase in global temperature. Apart from the increase of $\mathrm{CO}_{2}$ in the atmosphere, some $\mathrm{CO}_{2}$ is dissolved into the oceans and is transferred gradually to the deep ocean, and the carbon content in this reservoir is continuously increasing.

Although the prediction of consequences of global warming cannot be done with absolute certainty, the risk associated with certain increase in global mean temperature has been guesstimated. Some of the major impacts of global warming, if not confined, can be summarized as follows [2]:

- There will be sudden shifts in regional weather pattern including monsoon in South Asian region and El Nino. This may lead to changes in the spatial and time pattern of precipitation causing extreme rainfall and drought events.

- There will be rise in the sea level due to thermal expansion of the waters inundating the coastal areas. The increase in sea level may also be contributed by melting polar ice caps and glaciers, which in land would induce floods. Global mean sea level has been estimated to rise by about $49 \mathrm{~cm}$ in the year 1990-2100 considering current emission scenarios. However, considering the high emissions scenarios the rise has been estimated to about $110 \mathrm{~cm}$ for the same period [3].

- There will be catastrophic effects in the ecosystems of the planet. About $15 \%$ to $40 \%$ of species will face potential extinction even after only $2^{\circ} \mathrm{C}$ of warming. The increased level of carbon dioxide levels in the atmosphere results in ocean acidification, which will largely affect the marine ecosystems, with possible declination of fish stocks [2].

- The already warm region of the earth will have higher temperature leading to increased heat stress related deaths and increase the occurrence of tropical disease including malaria and dengue fever [2].

The above impacts will ultimately result in decrease in agricultural yields, large exodus, and conflicts over the share of resources including food, water and space. The changes in the regional climate may differ substantially depending on the geographical location. This implies that the impact of climate change might be more severe in one region than the other. Most of the developing countries including Nepal are in the already warm regions of the earth and is experiencing further increase in temperature. Over the last twenty-five years, the temperature in Nepal has been increasing at the rate of $0.06^{\circ} \mathrm{C}$ per year [4]. In high altitudes, it increased by $0.6^{\circ} \mathrm{C}$ over the last thirty years [4]. And it is almost certain that Nepal, along with the other developing countries will encounter greater impact of global warming in terms of decreased agricultural produce (which these countries' economy de- pend upon), shortage of water, mass migration, increases in diseases causing overburden to the already poor health sector. These impacts will further adversely affect the socioeconomic development of this part of the world. At this juncture, a country like Nepal must stand ahead to set an example as a low carbon society to the developed world. This will put moral pressure on the developed world to curtail their GHG emissions for a better future of the planet.

\section{Nepalese Scenario}

Nepal, together with more than other 150 other countries, signed the United Nations Framework Convention on Climate Change (UNFCCC) at the United Nations Conference on Environment and Development (UNCED) held in Rio de Janeiro in June 1992 [5]. Nepal ratified the Convention on 2nd May in 1994, and this convention came into force in Nepal on 31st July in 1994. As a nonAnnex country, Nepal is not required to curtail the GHG emissions. However, it has an obligation to prepare and periodically update the national green house gas inventory and submit "National Communications" to the UNFCCC. As a response to this obligation, Nepal completed Initial National Communication to the Conference of the Parties of the UNFCC in 2004 [4]. However the updates of the greenhouse gas inventory in recent years is yet to be done.

According to the estimation of GHG emissions in Nepal, the total contribution of the gases is very modest compared to other developing and developed countries at present and it is not very likely that the emissions will increase very much in the near future. Figure 1 compares $\mathrm{CO}_{2}$ emissions (in tons) from fuel combustion in Nepal with other developed and developing countries.

\section{GHG Mitigation and Low Carbon Society}

Low carbon society is a current effort of almost all countries of the world to respond climate change in an effecttive way. However, low carbon strategy itself requires

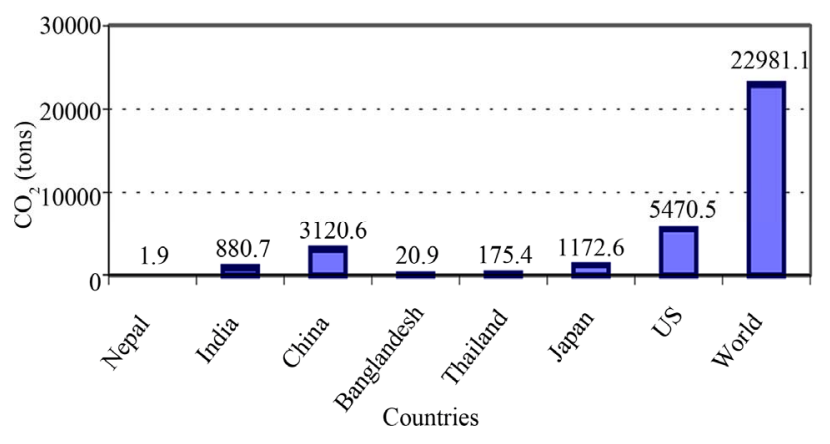

Figure 1. $\mathrm{CO}_{2}$ (tons) emissions from fuel combustion in 1997 [2]. 
visualizing social, economic and technological change through which societies respond to global effect of climate change. An overlook of any one of the dimensions social, economic or technological will not achieve the goal.

As discussed earlier that the earth cannot afford more than $2^{\circ} \mathrm{C}$ increase in its average temperature, both developing and developed world should consider development pathway with the $2^{\circ} \mathrm{C}$ global stabilization target.

To stabilize the emissions within the $450 \mathrm{ppmv}$ of $\mathrm{CO}_{2}$ in the atmosphere $\left(2^{\circ} \mathrm{C}\right.$ temperature rise in 2100$)$, there must be huge economic cost. Moreover, the country should prepare its different development path scenario including sustainable development while stabilizing carbon emissions within the limit. Different development models should be prepared after having comprehensive analysis of current economic, social and technological context along with the vision where we want to be in future.

In this study, we have proposed a conceptual framework for the preparation of a comprehensive strategy for the development of a low carbon society applicable to Nepal. In addition, we have focused on Energy Sector, which covers Residential, Transport, and Industrial (GHG emission from fossil fuel combustion in industries and not the industrial processes) where immense energy saving opportunities is present.

To develop carbon mitigation strategy of the country, first and foremost important factor is to know about potential GHG emission sectors and the share of it in total national GHG emissions. The potential sectors have been identified in which mitigation strategy and action plan can be implemented to make a low carbon society. In order to analyze the potential areas of GHG mitigation from energy consuming sector, we must have an overview of energy consumption pattern of Nepal.

\section{An Overview of Energy Consumption Pattern in Nepal}

Various countries have their own fuel diversification strategy to ensure that the country is not over-dependent one main energy sources [6]. However, Nepal has no policy on fuel diversification strategy and is heavily dependent on biomass energy. Nepal's energy resources are generally divided into three categories: Traditional, Commercial and Alternative [7]. Table 1 shows the distribution of energy consumption by various fuel types in 2008-2009. It is seen from Table 1 that the total energy consumption of the country is 401,000 TJ in 2008-2009. The largest share in energy distribution is met by fuel wood whose contribution is about $78 \%$ whereas other biomass resources like agriculture residue and animal dung contribute about $4 \%$ and $6 \%$. Share of petroleum fuels is
Table 1. Share of energy consumption by fuel types [7].

\begin{tabular}{ccc}
\hline Fuel Type & \% Share & 1000, GJ \\
\hline Fuel wood & 77.7 & 311577 \\
Agriculture residue & 3.7 & 14837 \\
Animal dung & 5.7 & 22857 \\
Petroleum & 8.2 & 32882 \\
Coal & 1.9 & 7619 \\
Biogas & 0.6 & 2406 \\
Electricity & 2 & 8020 \\
Solar and micro hydro & 0.2 & 802 \\
\hline
\end{tabular}

about $8 \%$ and the share of electricity in the total energy supply of the country is only about $2 \%$. The total energy consumption of 2008-2009 is about 9\% higher than the year of 2004-2005 with an annual average growth of 2.4\% [7].

The amount of energy consumption and its type are directly related to the population of a country and its economy. Increased supply of energy will enhance the rate of economic growth; however, this relation is not very strong in the present Nepalese context. However, in the future, energy may be one of the major determinants of economic growth due to the gradual shift of economy from traditional agriculture to industrial and commercial ones [8].

As seen in Table 1 the energy demand and supply structure of Nepal is such that it is met mostly by biomass resources including fuel wood, agriculture residue and animal waste.

The large share of fuel wood $(77.7 \%)$ in total energy supply has led to deforestation $(1.7 \%$ annual deforestation rate in 2008/2009 [7]), which has caused ecological imbalance in many sectors. Sustainable use of forest to meet national energy demand using energy efficient conversion technology like efficient cooking stoves and gasifiers are necessary to ensure ecological balance as well as to have energy security.

\subsection{Fuel Consumption by Sectors}

Table 2 illustrates fuel consumption by different sectors. It is crucial to have an idea of the fuel consumption by various sectors so that potential energy savings sectors can be identified. The table shows that residential sector consumes about $89 \%$ of total energy whereas transport sector consumes about $5 \%$ and the industrial sector consumes about 3\%. Commercial and agriculture sectors together consume approximately $2 \%$. From the table it is clear that energy saving and substitution, and less energy consumption practices in residential sectors is very crucial to move towards a low carbon society. Moreover, transport and industrial sectors are also potential sectors in which energy saving measures can be implemented. 
Table 2. Energy consumption by various sectors [7].

\begin{tabular}{ccc}
\hline Energy consumption by sector & \% Share & $\mathbf{1 0 0 0 , \text { GJ }}$ \\
\hline Residential sector & 89.1 & 357291 \\
Industrial sector & 3.3 & 13233 \\
Commercial sector & 1.3 & 5213 \\
Transport sector & 5.2 & 20852 \\
Agriculture sector & 0.9 & 3609 \\
Other & 0.2 & 802 \\
\hline
\end{tabular}

\subsubsection{Fuel Type in Residential Sector}

It is also relevant to explore the share of different fuel types in residential sector to estimate an amount of carbon emission from this sector. Table 3 depicts that about 89.1\% (357291 TJ) energy is consumed by residential sector out of which biomass resources are the major fuel sources in this sector namely fuel wood (86.5\%), agriculture residue (3.7\%) and the animal waste (6.5\%). Altogether about $97 \%$ energy in residential sector comes from biomass resources while share of electricity and liquidified petroleum gas (LPG) is about $1 \%$ each. As residential sector energy consumption is about $89.1 \%$ of total national energy consumption, the share of fuel wood is about $86.5 \%$. The use of animal waste is popular in Terai region of the country where fuel wood resources are not easily accessible due to several reasons.

The biomass energy that is being consumed in residential sector is usually in the form of thermal energy (i.e. in the form of cooking energy). The biomass energy conversion technology practiced in Nepal is generally conventional which implies that the energy conversion efficiency is very less. This means that the energy saving potential in residential sector is huge as more than $87 \%$ of total national energy consumption is met by biomass resources. Further, the effort for achieving energy efficiency and fuel diversification policy can reduce great amount of carbon emission and improve indoor air quality in residential sector [8]. Besides biomass energy, share of commercial energy in total national energy consumption is about $12 \%$, out of which $8 \%$ is shared by petroleum, $2 \%$ is shared by electricity and $2 \%$ is shared by coal.

\subsubsection{Fuel Type in Industrial Sector}

Industrial sector energy consumption is about 3.3\% $(13233 \mathrm{TJ})$ of the total national energy consumption in $2008 / 2009$, which is third largest energy consuming sector. Table 4 shows that coal, electricity and agricultural residue have larger shares in industrial energy. From this data it can be said that within the industrial sector the
Table 3. Share of different fuel used in residential sector [7].

\begin{tabular}{ccc}
\hline Fuel Type in residential sector & \% Share & $\mathbf{1 0 0 0 , \mathbf { G }}$ \\
\hline Fuel wood & 86.5 & $\mathbf{3 0 9 0 5 7}$ \\
Agri residue & 3.7 & $\mathbf{1 3 2 1 9 . 8}$ \\
Animal waste & 6.5 & $\mathbf{2 3 2 2 3 . 9}$ \\
LPG & 0.9 & $\mathbf{3 2 1 5 . 6}$ \\
Kerosene & 0.6 & $\mathbf{2 1 4 3 . 7}$ \\
Electricity & 1 & $\mathbf{3 5 7 2 . 9}$ \\
Biogas & 0.6 & $\mathbf{2 1 4 3 . 6}$ \\
Solar and micro hydro & 0.2 & $\mathbf{7 1 4 . 5}$ \\
\hline
\end{tabular}

Table 4. Energy consumption in industrial sector [7].

\begin{tabular}{ccc}
\hline Fuel type in industrial sector & \% Share & $\mathbf{1 0 0 0 , ~ G J ~}$ \\
\hline Coal & 57.7 & $\mathbf{7 6 3 5 . 4}$ \\
Diesel & 1.9 & $\mathbf{2 5 1 . 4}$ \\
Kerosene & 0.8 & $\mathbf{1 0 5 . 9}$ \\
Other petroleum & 0.9 & $\mathbf{1 1 9 . 1}$ \\
Electricity & 23.2 & $\mathbf{3 0 7 0 . 1}$ \\
Agriculture residue & 10.1 & $\mathbf{1 3 3 6 . 5}$ \\
Fuel wood & 5.4 & $\mathbf{7 1 4 . 6}$ \\
\hline
\end{tabular}

energy saving potential is high since many industrial processes and energy conversion technology are conventional where immense potential can be tapped by implementing energy efficiency measures.

\subsubsection{Fuel Type in Transport Sector}

While GHG emission is large in this sector, the emission reduction potential is also high. In general, emission reduction is possible by substituting high carbon intensive fossil fuel with less carbon intensive fuel, by improving road networks and by enforcing stringent measures to control emission from vehicles. Table 5 shows that fuel type energy consumption in transport sectors.

\subsubsection{Fuel Type in Agriculture Sector}

Energy consumption in agriculture sector is negligible as compared with other sectors as agricultural activities in Nepal are mostly traditional and uses of machineries are very less. Some of the energy consuming activities in this sector including operation of agro-machineries and irrigation, are mostly done by diesel. Only a small number of irrigation facilities are connected with electricity [8]. Since more than $95 \%$ of energy demand is met by diesel as shown in Table 6, which can be replaced by carbon neutral fuel, carbon emission reduction potential is high in this sector. 
Table 5. Energy consumption in transport sector [7].

\begin{tabular}{ccc}
\hline Fuel type in Transport Sector & \% Share & $\mathbf{1 0 0 0 , \text { GJ }}$ \\
\hline HS diesel & 67 & $\mathbf{1 3 9 7 0 . 8}$ \\
LS diesel & 0.1 & $\mathbf{2 0 . 8}$ \\
ATF & 11.9 & $\mathbf{2 4 8 1 . 4}$ \\
LPG & 1.1 & $\mathbf{2 2 9 . 4}$ \\
Gasoline & 19.9 & $\mathbf{4 1 4 9 . 6}$ \\
\hline
\end{tabular}

Table 6. Agricultural energy consumption [7].

\begin{tabular}{ccc}
\hline Fuel type in agriculture sector & \% Share & $\mathbf{1 0 0 0 , \text { G J }}$ \\
\hline Electricity & 4.8 & $\mathbf{1 7 3 . 2}$ \\
HS diesel & 95.1 & $\mathbf{3 4 3 2 . 1}$ \\
L diesel & 0.1 & 3.7 \\
\hline
\end{tabular}

\section{Proposed National Carbon Mitigation Strategy}

\subsection{Scope of the Strategy}

The idea of low carbon society has originated as a response to mitigate greenhouse gases (GHGs), which are considered to be responsible for global warming and climate change. A national carbon mitigation strategy must be developed in order to mature an idea of low carbon society. However, in developing countries like Nepal having very low per capita emissions (as well as total emissions), and still needing to meet basic development needs including education, healthcare and the like. This is a problem with the developing countries. Therefore, Nepal might not be able to afford concentrated focus on deep emission cuts development pathway, which might incur massive cost of development. Nevertheless, it should prepare to opt for one of the emerging and accepted approaches to overcome development paradox that is through sustainable development (SD). The sustainable development pathway results in lower emission mitigation costs in addition to creating opportunities to realize co-benefits without compromising the original objective of enhancing economic and social development. Such co-benefits include improved air (indoor, outdoor) quality and associated social cost reduction [11]. Moreover, the cost (GDP loss) associated with low carbon development pathway (sustainable development pathway) can be compensated through international financial assistance (direct financial assistance, technological transfer or carbon trading mechanism like CDM etc.).

Also, to meet the demand of low carbon emission and to continue the economic development would be possible if the country prepares a strategy and action plan to combat the future scenario in advance. Hence, for realizing the vision of low carbon society, a comprehensive policy instruments as well as technological options are required for implementation of the carbon mitigation measures [12]. To realize GHG mitigation strategy a set of procedure is being proposed.

\subsection{Methodology}

A deep national economy crisis, unstable national economy and baffling national development plans significantly complicates the estimation of future GHG emissions. However, to prepare an effective carbon mitigation strategy a set of policy as well as technological intervention is necessary. A cautious evaluation of the following steps is recommended:

- Preparation of accurate national GHG inventory (from energy and non-energy sectors);

- Accurate identification of the sources and causes of GHG emissions;

- Project long term GHG emissions on different scenario of development pathway (use simulation tools and models);

- Development of baseline scenario of emissions and its projection;

- Accurate analysis of mitigation measures in all sectors in different scenarios (fuel switch, energy efficiency, reforestation, animal feed change, crop change etc.);

- Estimation of cost associated with GHG reductions in different sectors on national targets;

- Development of national annual mitigation targets;

- Development of mitigation scenarios and its cobenefits.

GHG emissions are directly linked to economic prosperity of the nation and long term development goal of the country. Based on this development goal and economic prosperity of the nations, accurate GHG projections can be done, which requires consideration of national plan on energy security, land use policy and reforestation programs. The country should formulate its energy policy, land use policy and use of forest policy compatible with national GHG mitigation strategy.

\subsection{Potential Area for Mitigation}

Based on energy consumption in 2008/2009, carbon emission on different sectors are evaluated and shown in Figure 2, however, in this calculation emission from traditional fuels and electricity is assumed to be zero. But even if we have sustainable use of forest and net carbon emission is zero, there can be unnecessary loss of useful energy and high indoor air pollution due to the use of conventional energy conversion technology. The use of efficient energy conversion technology might save tremendous amount of 


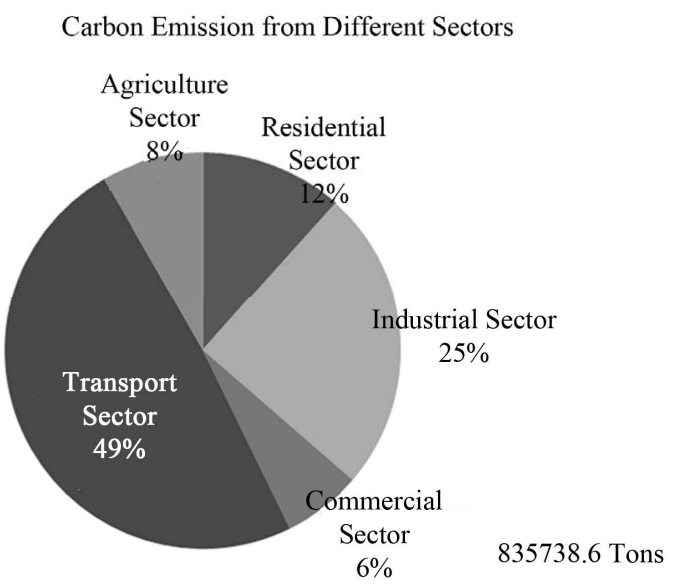

Figure 2. GHG emissions from different energy consuming sectors in Nepal.

energy as well as improve indoor air pollution reducing health risk, especially of women and children who are generally exposed to the pollutants for longer time. Saving energy is equivalent to reducing GHG emissions. Some potential areas of mitigation are discussed below.

\subsubsection{Residential Sector}

Energy consumption in residential sector is about $89 \%$ of total national energy consumption of which $97 \%$ is traditional fuel (basically biomass). Almost all traditional fuel in residential sector is used for cooking food, space heating and so on. The use of cooking stoves or energy conversion technology practice in Nepal is generally open hearth cooking stoves having efficiency of around 5\% $7 \%$ which is very modest. This implies that lots of energy is lost in the surroundings and at the same time emitting higher amounts of pollutants. If the less efficient stoves are replaced by improved cooking stoves and gasifiers having efficiency more than $15 \%$, half of the fuel can be saved. The target to achieve $15 \%$ - $20 \%$ efficiency on gasifiers and improved stoves is not an ambitious target and can be achieved easily. By having efficient cooking methods, about 175,000 TJ energy can be saved annually (figure for 2008/2009), which further lead to huge amount of carbon emission reduction. This in turn reduces pressure on forest and ecosystem. This carbon reduction potential can be benefited from carbon trading mechanism like CDM.

The share of LPG, kerosene and electricity is about $2.5 \%$ of the total energy consumption in residential sector, out of which $0.9 \%$ is contributed by LPG, $0.6 \%$ is contributed by kerosene and $1 \%$ is contributed by electricity.

The potential to substitute LPG and kerosene by biogas is evident, which also can be benefited from carbon trading mechanism. Moreover, those fossil based fuels can also be replaced by electricity (hydroelectricity) if country has abundant electricity generation. The current market price per unit of energy from LPG and electricity is almost the same. Therefore, there is an enormous potential to shift fuel types in residential sector which will certainly reduce dependency on imported fuels and save foreign currency while reducing emissions. Energy efficient measures in use of electricity can reduce use of electricity consumption. These measures are efficient light (CFL), efficient electrical appliances etc.

\subsubsection{Transportation Sector}

The transport sector has nearly half (49\%, 409101.6 Tons) of GHG emission share in total national GHG emission. The reason of the large share of emission from the transport sector is due to the use of fossil fuels in this sector.

Therefore, this sector should be given highest priority in view of future action plan of carbon mitigation strategy. Moreover, the detail and accurate GHG inventory of transport sector is required to formulate the carbon mitigation plan. The mitigation target in this sector can play a decisive role on how and what kind of measures can be taken to achieve the goal. Increased use of biodiesel and bioethanol in diesel and petrol fuel respectively, phasing out of vehicles that are not complying the emissions standards, promoting electric vehicles and mass transit systems, improving road networks and identifying the vehicle acceptance limit based on road networks and traffic management, could be useful measures for reducing carbon emissions from transport sectors. If the above measures are applied, approximately $15 \%$ - 20\% reduction can be possible.

\subsubsection{Industrial Sector}

Industrial sector has second largest carbon contribution (25\%, 206494.9 Tons) in national carbon emission which is also due to the large share of fossil fuels in its total energy consumption. Improving energy efficiency in industrial sectors (basically on boilers, furnaces, lighting and electric motors etc.) can reduce huge amount of carbon emission but the detail investigation of associated economic cost per unit of emission reduction should be identified in order to formulate an action plan of carbon mitigation strategy. Besides the sectors discussed above, energy related GHG emission reduction potential in non energy sector (agriculture and forestry) is also possible.

\subsubsection{Forestry Sector}

The potential to store carbon in the Nepalese forest biomass is shown in Table 7 [4]. It shows that there is great potential for storage of $\mathrm{CO}_{2}$ in the forest biomass. If forest growth rate is positive then the growing biomass could easily offset $\mathrm{CO}_{2}$ emissions from other sectors. The amount of $\mathrm{CO}_{2}$ offset will depend on the magnitude of growth rate of the forest and the amount of $\mathrm{CO}_{2}$ emitted. 
Table 7. Forest areas and carbon stored in various development regions of Nepal [4].

\begin{tabular}{|c|c|c|c|c|c|c|c|}
\hline \multirow{2}{*}{ SN } & \multirow{2}{*}{ Development regions } & \multicolumn{2}{|c|}{ Forest area (in million/ha) } & \multicolumn{2}{|c|}{ Above-ground biomass (in million/tonnes) } & \multicolumn{2}{|c|}{ Carbon (in million/tonnes) } \\
\hline & & 1986 & 1994 & 1986 & 1994 & 1986 & 1994 \\
\hline 1 & Far western & 0.991 & 0.687 & 128.0 & 161.1 & 64.0 & 80.55 \\
\hline 2 & Mid western & 1.641 & 1.192 & 229.0 & 219.4 & 114.5 & 109.7 \\
\hline 3 & Western & 0.900 & 0.734 & 81.0 & 143.5 & 40.5 & 71.75 \\
\hline 4 & Central & 1.063 & 0.919 & 109.0 & 183.3 & 54.5 & 91.65 \\
\hline \multirow[t]{2}{*}{5} & Eastern & 0.923 & 0.736 & 81.0 & 165.7 & 40.5 & 82.85 \\
\hline & Total & 5.518 & 4.268 & 628.0 & 873.0 & 314.0 & 436.5 \\
\hline
\end{tabular}

from other sectors. This can be calculated only if proper GHG inventory is available. For a developing country like Nepal, the forestry sector alone can offset the GHG emissions from the entire sectors. Emission reductions due to avoided deforestation is considered to be a very costeffective future climate change policy [2]. The program, REDD (Reducing Emissions from Deforestation and Forest Degradation) in developing countries are targeted to reduce deforestation, and to provide important opportunity for developing countries to contribute significantly in emission reduction efforts under the international climate regime. In addition, many accompanying benefits, including environmental service from reducing deforestation, could be expected.

\subsubsection{Agricultural Sector}

The agricultural sector emits carbon dioxide due to land use change (mainly deforestation for new agriculture areas), and fossil fuel usage for irrigation and agro processing. While agriculture emits only small amounts of $\mathrm{CO}_{2}$, it has a large capacity to store carbon in plant material and soils. Implementing certain best management practices in agriculture, such as, conservation tillage, nutrient management, rotational grazing and improved forage management, use of cropping rotations and cover crops, can increase the potential for greater $\mathrm{CO}_{2}$ storage [12]. The GHG emissions from this sector can be minimized by the promotion of several sustainable agricultural practices including crop cycling, no tillage cropping, organic farming, and occasional drainage of flooded rice field Nepal being an agricultural country, this sector not only has a huge potential of reducing GHG emission but also has a great potential to serve as carbon sink in the form of agricultural biomass in the soil. This needs lots of awareness and education in addition to the research on how agricultural system of Nepal can be made sustainable and yet cost effective.

\section{Expected Structure of the National Carbon Mitigation Strategy}

To envision a low carbon society along with noticeable economic development, growing use of commercial fuels and lessening use of biomass sources are imperative factors. Since Nepal does not have any other energy resources (except hydropower) its efforts should be concentrated on harnessing hydro power resources, enhancing use of renewable energy sources and improving energy efficiency of the existing system. Here a proposed carbon mitigation strategy frame is presented in Table $\mathbf{8}$ as a reference for the formulation of national carbon mitigation strategy.

\section{Conclusions}

A review of GHG emission sources and their mitigation potential in various sectors has been done. On the basis of the experiences from around the world it can be concluded that Nepal has ample opportunities not only to reduce GHG emissions from its existing amount but also to serve as carbon sink. Based on the practice and success stories from elsewhere, Nepal can devise its own strategy to mitigate greenhouse gases. The tentative strategy has also been proposed. However, in order to have concrete strategy the detail GHG emission inventory and development vision of Nepal are crucial. Without a proper database of the GHG emission of the country and the development vision the usefulness and success of the strategy in terms of cost effectiveness and sustainability cannot be evaluated. Thus, further works on estimating GHG emissions from various sector using contemporary tools and techniques along with the projection of long term development goals of the country is highly recommended.

\section{Acknowledgements}

The Alternative Energy Promotion Canter, Ministry of En- 
Table 8. Expected structure of the national carbon mitigation strategy.

\begin{tabular}{|c|c|c|}
\hline Policy instruments & Framework & Actions \\
\hline Develop national energy policy & $\begin{array}{l}\text { Set energy mix target } \\
\text { Fuel diversification strategy } \\
\text { Promote indigenous energy resources }\end{array}$ & $\begin{array}{l}\text { Fuel switch from coal, diesel, LPG to electricity and other } \\
\text { renewable } \\
\text { Research and development to promote cleaner energy }\end{array}$ \\
\hline Develop energy efficiency policy & $\begin{array}{l}\text { Device efficiency standardization } \\
\text { Fees, Taxes and subsidies to stimulate } \\
\text { efficient technology }\end{array}$ & $\begin{array}{l}\text { Energy and environment audits } \\
\text { Research and development to set national efficiency stan- } \\
\text { dards and penalties }\end{array}$ \\
\hline Sustainable transport policy & $\begin{array}{l}\text { Promotion of biofuels } \\
\text { Promoting electric vehicles } \\
\text { Better traffic management } \\
\text { Mass based transit system }\end{array}$ & $\begin{array}{l}\text { Research and development on biofuels and electric vehicles } \\
\text { adaption } \\
\text { Enforcement of traffic regulations } \\
\text { Improve road networks and prepare bus and route timetables } \\
\text { Shift from private to public transport (bus, train, tram) }\end{array}$ \\
\hline Reduced carbon policy & $\begin{array}{l}\text { Emission trading } \\
\text { Tax system-environmental tax, greener } \\
\text { tax system } \\
\text { Set carbon footprints }\end{array}$ & $\begin{array}{l}\text { Project based on carbon trading mechanism } \\
\text { Tax incentives for less or no GHG emission } \\
\text { Life cycle analysis to display carbon emission-footprints }\end{array}$ \\
\hline Waste management & Reduce, reuse, recycle & $\begin{array}{l}\text { Minimize waste disposal, recycle waste } \\
\text { Encourage composting, anaerobic digestion } \\
\text { Harness methane from landfill }\end{array}$ \\
\hline Land use and land use change & Sustainable agriculture & $\begin{array}{l}\text { Promote agroforestry } \\
\text { Promotion of organic farming } \\
\text { Promotion of integrated farming }\end{array}$ \\
\hline $\begin{array}{l}\text { Reduced deforestation and degra- } \\
\text { dation of forest (REDD) }\end{array}$ & $\begin{array}{l}\text { Community forest user groups } \\
\text { Market based mechanism to reward for- } \\
\text { est conservation } \\
\text { Stringent measures to curb deforestation }\end{array}$ & $\begin{array}{l}\text { Afforestation program, Sustainable use of forest } \\
\text { Set annual growth targets, Maintain standard data bank } \\
\text { Severe punishment }\end{array}$ \\
\hline $\begin{array}{l}\text { Low carbon and sustainable socie- } \\
\text { ties }\end{array}$ & $\begin{array}{l}\text { Teaching and learning about low carbon } \\
\text { and sustainable societies }\end{array}$ & $\begin{array}{l}\text { Course plan in every educational level } \\
\text { Collaborating with groups and individuals working with these } \\
\text { issues }\end{array}$ \\
\hline
\end{tabular}

vironment, Government of Nepal is acknowledged for the financial support of this project.

\section{REFERENCES}

[1] Climate Change Enabling Activity Project, CMB/97/G31, Ministry of Environment, "Greenhouse Gas Mitigation Analysis Land Use Change and Forestry, and Agriculture," Cambodia, 2001.

http://cstn.files.wordpress.com/2009/12/ghg-mitigation-n on-energy-en.pdf.

[2] N. Stern, "Stern Review: The Economics of Climate Change,” 2011. http://www.hm-treasury.gov.uk/stern_review_report.htm

[3] S. Dhakal, “Climate Change Initiatives and Nepal,” Technical Journal, No. 1, 2001, pp. 24-31.

[4] B. N. Oli and K. Shrestha, "Carbon Status in Forests of Nepal: An Overview,” Journal of Forest and Livelihood, Vol. 8, No. 1, 2009, pp. 62-66.

[5] HMG Ministry of Population and Environment, "Initial National Communication to the Conference of the Parties of the United Nations Framework Convention on Climate Change," 2004. http://unfccc.int/resource/docs/natc/nepnc1.pdf
[6] H. T. Oh, Y. S. Pang and C. S. Chau, "Energy Policy and Alternative Energy in Malaysia: Issues and Challenges for Sustainable Growth,” Renewable and Sustainable Energy Reviews, Vol. 14, 2010, pp. 1241-1252. doi:10.1016/ j.rser.2009.12.003

[7] WECS, “Energy Synopsis Report,” Water and Energy Commission Secretariat, Nepal, 2010. http://wec.gov.np/downloadfile/snyopsis_1320236106.pdf

[8] K. S. Yogacharya and L. M. Acharya, "Mitigation Assessment of Green House Gases Emissions for Energy Sector in Nepal,” Draft Report, 1996. http://www.gcrio.org/CSP/pdf/nepal_mitop.pdf

[9] “Energy for Sustainable Development," Module 1-3, Lund University, Lund, 2009.

[10] “Energy for Sustainable Development," Module 1-2, Lund University, Lund, 2009.

[11] Climate Change Enabling Activity Project, CMB/97/G31 Phase 2, Ministry of Environment, “Assessment of Greenhouse Gas Mitigation Technologies for Non-Energy Sector in Cambodia,” Cambodia, 2003, pp. 1-6.

[12] E. Branosky and S. Greenhalgh, "Agriculture and Climate Change: Greenhouse Gas Mitigation Opportunities and the 2007 Farm Bill," WRI Policy Note-Climate: Agri- 
culture, No. 2, World Resources Institute, 2007.

[13] U. Niggli, A. Fliessbach, P. Hepperly and N. Scialabba, "Low Greenhouse Gas Agriculture: Mitigation and Adaptation Potential of Sustainable Farming Systems,” FAO, April 2009.

[14] C. Gerald, G. C. Nelson, R. Robertson, S. Msangi, T. Zhu, X. Liao and P. Jawajar, "Greenhouse Gas Mitigation-Issues for Indian Agriculture,” IFPRI Discussion Paper 00900, International Food Policy Research Institute, 2009.
[15] P. R. Shukla, “Low Carbon Society Vision 2050,” India, 2009.

[16] P. R. Shukla, “India’s GHG Emission Scenarios: Aligning Development and Stabilization Paths," Current Science, Vol. 3, 2009, pp. 384-395.

[17] N. V. Raptsoun and N. V. Parasyuk, "Assessment of GHG Mitigation Measures in Ukraine,” Applied Energy, Vol. 56, 1997, pp. 367-380. doi:10.1016/S0306-2619(97)00017-2

\section{Abbreviation}

GHG

ppmv

UNFCCC

UNCED

SD

CDM

CFL

LUCF

LPG

LCS

GDP
Green House Gas

Parts per million volume

United Nations Framework Conventionon

Climate Change

United Nations Conference on

Environment and Development

Sustainable Development

Clean Development Mechanism

Compact Fluorescent Lamp

Land use change and forestry

Liquid Petroleum Gas

Low Carbon Society

Gross Domestic Product

\section{Nomenclature}

$\mathrm{CO}_{2}$

$\mathrm{CH}_{4}$

$\mathrm{N}_{2} \mathrm{O}$

HFCs

PFCs

$\mathrm{SF}_{6}$

$\mathrm{CO}$

NMVOCs

TJ

$\mathrm{M}$

GJ
Carbon Dioxide

Methane

Nitrous Oxide

Hydrofluorocarbons

Perfluorocarbons

Sulphur Hexafluoride

Carbon Monoxide

Non-Methane Volatile Organic

Compounds

Tera Joule

Million

Giga Joule 